\title{
Mesangial Cell Apoptosis: The Major Mechanism for Resolution of Glomerular Hypercellularity in Experimental Mesangial Proliferative Nephritis
}

\author{
Amanda J. Baker, * Andrew Mooney, Jeremy Hughes, * Donna Lombardi, ${ }^{\star}$ Richard J. Johnson, ${ }^{\star}$ and John Savill \\ Division of Renal and Inflammatory Disease, Department of Medicine, University Hospital, Nottingham NG7 2UH, United Kingdom; \\ * Renal Unit, Department of Medicine, Royal Postgraduate Medical School, Hammersmith Hospital, London W12 ONN, United \\ Kingdom; and ${ }^{\ddagger}$ Division of Nephrology, Department of Medicine, University of Washington, Seattle, Washington 98195
}

\begin{abstract}
Increases in mesangial cell number may herald glomerular scarring, but they are not irreversible. This study sought mechanisms by which surplus glomerular mesangial cells can be cleared. A small proportion of cultured mesangial cells exhibited typical morphological features of apoptosis (programmed cell death), which was increased by growth factor deprivation or exposure to cycloheximide, stimuli known to increase apoptosis in other cell types. Apoptosis was confirmed by typical internucleosomal chromatin cleavage. In vivo, clear morphological evidence of mesangial apoptosis leading to phagocytosis by neighboring mesangial cells was obtained in self-limited mesangial proliferation induced in rats by Thy1.1 antibody, apoptosis occurring $\sim 10$ fold more frequently than in the healthy rat glomerulus. Indeed, changes in glomerular cell number in Thy1.1 nephritis strongly suggested that apoptosis is the major cell clearance mechanism counterbalancing cell division, thereby mediating resolution of glomerular hypercellularity in experimental mesangial proliferation. (J. Clin. Invest. 1994. 94:2105-2116.) Key words: mesangial cell • apoptosis - glomerulonephritis • resolution • injury
\end{abstract}

\section{Introduction}

Post-inflammatory scarring is a common cause of disease in a number of organs, including the lung, joint, and gut. Indeed, this poorly understood condition is particularly important in the kidney, where it accounts for most cases of chronic renal failure requiring renal replacement therapy. In glomerular disease, increases in number of mesangial cells often herald sclerosis and loss of function. Moreover, this is the case not only in glomerulonephritis, but also in diabetic glomerulopathy, a further important cause of renal failure. Glomerular mesangial cells are thought to play a key role in promoting glomerular scarring as they elaborate extracellular matrix, secrete proinflammatory cytokines and regulate glomerular blood flow (1-3). Consequently, a major focus for research into the pathogenesis of

Amanda J. Baker and Andrew Mooney contributed equally to this work. Address correspondence to Professor John Savill, Division of Renal and Inflammatory Disease, Department of Medicine, University Hospital, Nottingham NG7 2UH, United Kingdom.

Received for publication 26 April 1994 and in revised form 8 July 1994.

J. Clin. Invest.

(C) The American Society for Clinical Investigation, Inc. 0021-9738/94/11/2105/12 \$2.00

Volume 94, November 1994, 2105-2116 glomerulosclerosis has been to define mechanisms underlying proliferation of glomerular mesangial cells in vitro and in vivo $(2,4-7)$.

However, accumulation of mesangial cells does not inevitably lead to glomerular scarring. In many disease states mesangial proliferation may resolve, allowing glomerular structure and function to return to normal (8). This point is emphasized by self-limited mesangial proliferation induced in rats by administration of antibody to Thy 1.1, in which mesangial cell number spontaneously returns to normal after a period of intense mesangial proliferation induced by antibody-mediated glomerular injury $(9,10)$. Therefore, observations in human glomerular disease and animal models demonstrate that there must be mechanisms by which excess mesangial cells can be cleared from the glomerulus. However, these have received scant attention despite the obvious fact that mesangial cell number is determined by the balance between cell division and disposal. Indeed, the fate of surplus mesangial cells has been obscure.

In many other tissues it is now increasingly recognized that unwanted cells are cleared by undergoing "programmed" cell death or apoptosis, which eliminates cells without inciting an inflammatory response. This is because cells dying by apoptosis are swiftly recognized and ingested by phagocytes before release of toxic contents, unlike accidental cell death or necrosis $(11,12)$. Apoptosis is tightly regulated by complex interplay between factors extrinsic and intrinsic to the cell $(12,13)$, as exemplified by the precise matching of cell deletion by apoptosis to cell birth by mitosis in healthy tissues undergoing normal turnover, where cell numbers remain constant. Apoptosis is also inconspicuous because only a small portion of the program can be detected by conventional histology. Thus, once chromatin condensation and other morphological changes typical of apoptosis occur, often many hours after cell death is triggered, measurements in a number of tissues indicate that uptake and degradation of apoptotic cells by phagocytes is so swift that only $0.5-2.0 \mathrm{~h}$ elapse before such cells are no longer histologically recognizable, the so-called clearance time (11, 14-16). Consequently, apparently small changes in the absolute number of apoptotic cells in a tissue may have dramatic consequences; a rise in apoptotic index of $1 \%$ without a commensurate change in mitosis could result in loss from a tissue of as many as $24 \%$ of cells over a $24-\mathrm{h}$ period if the clearance time is $1 \mathrm{~h}$.

Apoptosis therefore represents a candidate mechanism for removal of large numbers of excess mesangial cells which might have been easily overlooked in preceeding studies of nephritis. Indeed, such a role was cautiously proposed in the original description of apoptosis in biopsies taken at a single time point in the course of various types of human glomerulonephritis (17). Nevertheless, there were no data to demonstrate that the program of apoptosis is available to the activated myofibroblast- 
like mesangial cells of diseased glomeruli $(18,19)$. Indeed, in vitro study of the best available model of such cells, cultured mesangial cells, has suggested that they might be particularly resistant to this form of cell death. Thus, cultured mesangial cells can elaborate a number of growth factors with demonstrated or potential autocrine effects (4). Furthermore, mesangial cells may apparently remain in a quiescent and viable state for many days in vitro in the presence of minimal added growth factors $(1,4)$.

The purpose of this study was to examine the hypothesis that glomerular mesangial cell apoptosis is a mechanism capable of mediating mesangial cell clearance during resolution of mesangial proliferative nephritis. We found that the program of apoptosis is available to mesangial cells in vitro, occurring at low levels in cycling cultures of mesangial cells, and increased by deprivation of growth factors and by cycloheximide. In vivo, histological study in the Thy1.1 rat model of self-limited mesangial proliferative nephritis revealed unequivocal evidence of apoptosis in the mesangium, leading to phagocytosis of apoptotic cells by neighboring mesangial cells. Apoptosis was greatly increased when compared with the normal rat glomerulus, and the balance between the increased frequencies of apoptosis and mitosis strongly suggested that apoptosis was the major mechanism mediating resolution of glomerular hypercellularity in the Thy1.1 model.

\section{Methods}

Tissue culture materials. All reagents were from Sigma Chemical Co. (St. Louis, MO) unless otherwise stated. Culture media (RPMI 1640) and supplements ( $100 \mathrm{U} / \mathrm{ml}$ penicillin, $100 \mu \mathrm{g} / \mathrm{ml}$ streptomycin, $2 \mathrm{mM}$ glutamine, 10\% FCS and insulin/selenium/transferrin growth supplement) were from Gibco Laboratories (Grand Island, NY). Sterile tissue culture plasticware was from Falcon Plastics (Cockeysville, MD).

Culture of mesangial cells. Mesangial cells were prepared by standard methods of serial culture/trypsinization in tissue culture flasks of adherent outgrowth cells from glomeruli obtained by sieving of kidney cortex, as described $(1,20,21)$. Kidneys were from humans (normal cortex from organs removed for renal cell carcinoma), pigs, and Wistar rats. Cells were cultured in RPMI 1640 with $10 \%$ FCS and supplements as above, including $5 \mathrm{ml} / 500 \mathrm{ml}$ growth supplement $(25 \mathrm{mg} / \mathrm{ml}$ insulin from bovine pancreas, $25 \mathrm{mg} / \mathrm{ml}$ human transferrin, and $25 \mu \mathrm{g} / \mathrm{ml} \mathrm{so-}$ dium selenite). The cells were used between passages 4 and 6 after subculture into 24-well plates. Considerable care was taken to verify the phenotype and purity of mesangial cells, as in our previous studies $(20,21)$. Mesangial cells exhibited typical stellate morphology when subconfluent, while upon becoming confluent they adopted the wellrecognized elongated conformation; if cultured beyond confluence typical "hillocks" were seen (1). Upon electron microscopy (EM) ${ }^{1}$ ( see below), mesangial cells exhibited characteristic features such as abundant microfilaments, and, upon immunofluorescence, they contained organized $\alpha$-smooth muscle actin (not shown; previously presented in reference 21 ), excluding the remote possibility that these cells were fibroblasts. There was no evidence that macrophages had persisted to contaminate mesangial cell cultures; these cells did not exhibit macrophage markers such as leukocyte functional antigen-1 integrin expression (assessed by immunofluorescence flow cytometry) or acetylated LDL uptake, nor did they exhibit macrophage functional properties such as phagocytosis of opsonized zymosan particles. Furthermore, in

1. Abbreviations used in this paper: EM, electron microscopy; PI, propidium iodide; TdT, terminal deoxynucleotidyl transferase; TUNEL, TdT-mediated dUTP-biotin nick end labeling. addition to lack of acetylated LDL uptake, lack of immunostaining for Factor VIII-related antigen and cytokeratin excluded contamination with glomerular endothelial or epithelial cells, respectively (data not shown).

Morphology of cultured mesangial cells. Cells were examined by a number of morphological techniques to confirm apoptosis.

Inverted fluorescence microscopy of undisturbed mesangial cell cultures, to which was added acridine orange dye at a final concentration of $10 \mu \mathrm{g} / \mathrm{ml}$, was used to quantify apoptosis. Apoptotic cells were readily identifiable by shrinkage and condensation of chromatin (reference 22; see also Fig. 4).

Oil-immersion light microscopy of May-Giemsa cytospins was used to confirm apoptosis in cells detaching from the monolayer after growth factor deprivation. Cells were harvested from supernatant by centrifugation ( $275 \mathrm{~g}$ for $4 \mathrm{~min}$ ), and viability was checked by trypan blue exclusion.

EM was performed on pellets of harvested detached cells and on sections through adherent cultures of mesangial cells taken in planes parallel to the culture substrate. After fixation in $2 \%$ glutaraldehyde, cells were washed in phosphate buffer, osmicated, and dehydrated in a series of graded alcohols before being suspended in Taab resin and polymerized at $60^{\circ} \mathrm{C}$ overnight. Sections of $1 \mathrm{~mm}$ were cut and stained with toluidine blue for observation at light microscopy level. Ultrathin sections of $\sim 100 \mathrm{nM}$ were then cut, collected on nickel grids, and stained with uranyl acetate and lead citrate, for observation on a Philips CM10 electron microscope.

Induction and assay of apoptosis in cultured mesangial cells. Growth factor deprivation was achieved by gentle washing $(\times 2)$ and then incubation of adherent mesangial cell cultures in RPMI 1640 medium with no added supplements. In each experiment some wells were returned to full medium (i.e., RPMI 1640 plus $10 \%$ FCS and insulin/ selenium/transferrin growth supplement) as a control. Cells were then incubated at $37^{\circ} \mathrm{C} / 5 \% \mathrm{CO}_{2}$ for periods of up to $8 \mathrm{~h}$, a separate plate was used at each time point to ensure cell incubation was not interrupted. Apoptosis was quantified by inverted fluorescence microscopy after addition of acridine orange to otherwise undisturbed wells. Total cell number and apoptotic cells were counted first in the plane of the monolayer and then, by altering the plane of focus, in the supernatant above. Three randomly selected fields in each well were counted, and three wells were examined for each culture condition at every time point.

Cycloheximide was included at a final concentration of $50 \mu \mathrm{M}$ in RPMI 1640 medium without added supplements or FCS in some experiments.

Demonstration of DNA cleavage in cultured mesangial cells. Oligonucleosomal chromatin cleavage typical of apoptosis was sought in mesangial cells by standard techniques $(23,24)$. Briefly, harvested mesangial cells were washed twice in HBSS and then lysed with NTE ( $100 \mathrm{mM} \mathrm{NaCl}, 10 \mathrm{mM}$ Tris, $1 \mathrm{mM}$ EDTA) buffer, $\mathrm{pH} \mathrm{8}$, containing $1 \%$ SDS and proteinase $\mathrm{K}(0.2 \mathrm{mg} / \mathrm{ml})$. After incubation at $37^{\circ} \mathrm{C}$ for $12 \mathrm{~h}$, samples were extracted twice with 1:1 ( $\mathrm{vol} / \mathrm{vol})$ phenol and chloroform:isoamylalcohol $(24: 1, \mathrm{vol} / \mathrm{vol})$. Samples were then precipitated in $80 \%(\mathrm{vol} / \mathrm{vol})$ ethanol at $-20^{\circ} \mathrm{C}$. The DNA was dissolved in $12 \mu \mathrm{l}$ TBE ( $89 \mathrm{mM}$ Tris, $89 \mathrm{mM}$ boric acid, $2 \mathrm{mM}$ EDTA) buffer, $\mathrm{pH}$ 8.4 , and to each sample $3 \mu \mathrm{l}$ loading buffer was added containing $15 \%$ (wt/vol) Ficoll 400, 0.5\% SDS, $50 \mathrm{mM}$ EDTA, 0.05\% bromophenol blue, and $0.05 \%(\mathrm{vol} / \mathrm{vol})$ xylene cyanol in TBE buffer. The samples, together with ADNA (EcoRI) size markers, were loaded onto a 1\% (wt/ vol) agarose gel containing ethidium bromide ( $30 \mu \mathrm{g} / \mathrm{ml})$, electrophoresed at $60 \mathrm{~V}$ for $3 \mathrm{~h}$, and then viewed by ultraviolet light.

Histological analysis of Thyl.1 nephritis. Mesangial proliferative nephritis was induced in normal male Wistar rats (Simonsen Laboratories, Inc., Gilroy, CA), $240-260 \mathrm{~g}$, by a single intravenous injection of $0.2 \mathrm{ml} / 100 \mathrm{~g}$ goat anti-Thy1.1 antiserum $(9,10,25)$. In a pilot study, 24 rats were used, and 4 animals were killed at time 0 and at 5, 10, 14, 21 , and $42 \mathrm{~d}$ after injection. In a second study, four rats were killed at time 0 and $3,5,7,10$, and $14 \mathrm{~d}$; two animals were also killed at $8 \mathrm{~h}$ to ensure early mesangiolysis. In each case the left kidney was removed, cut into pieces, and immediately fixed. 


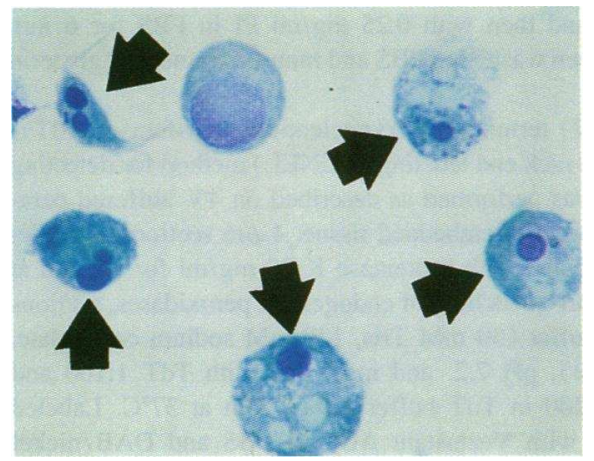

Figure 1.
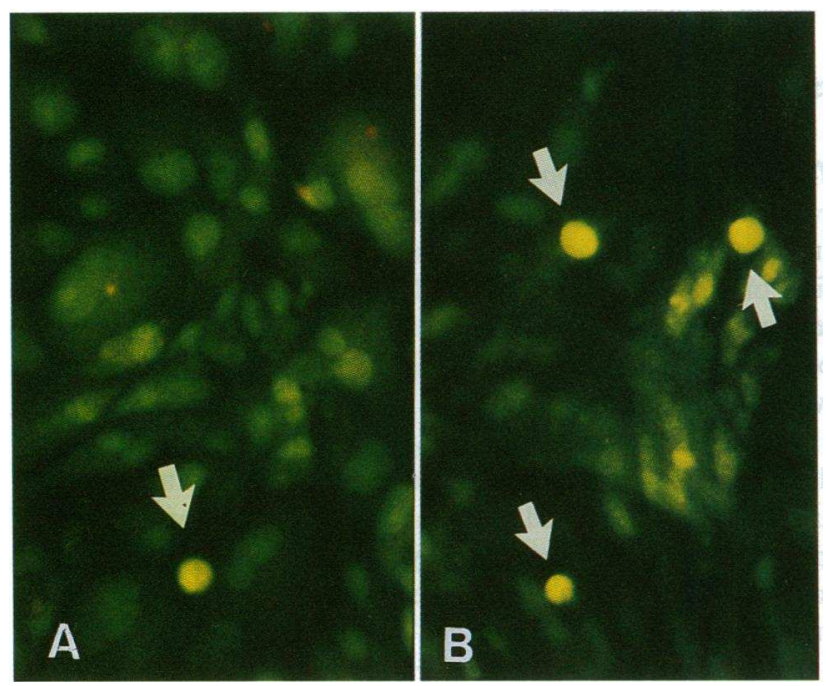

Figure 4.

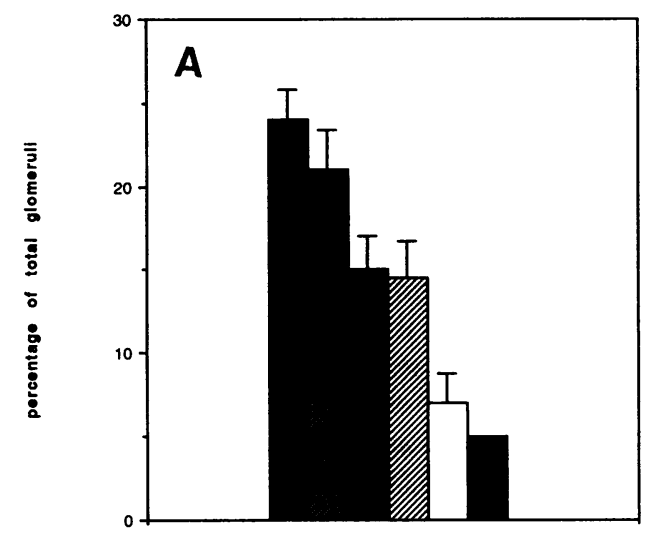

percentage of glomeruli with mitoses,
apoptoses, neither, or both, at day 5

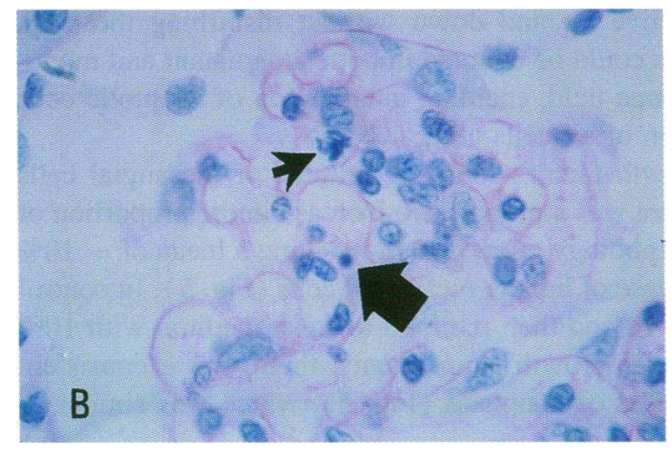

Figure 11 .
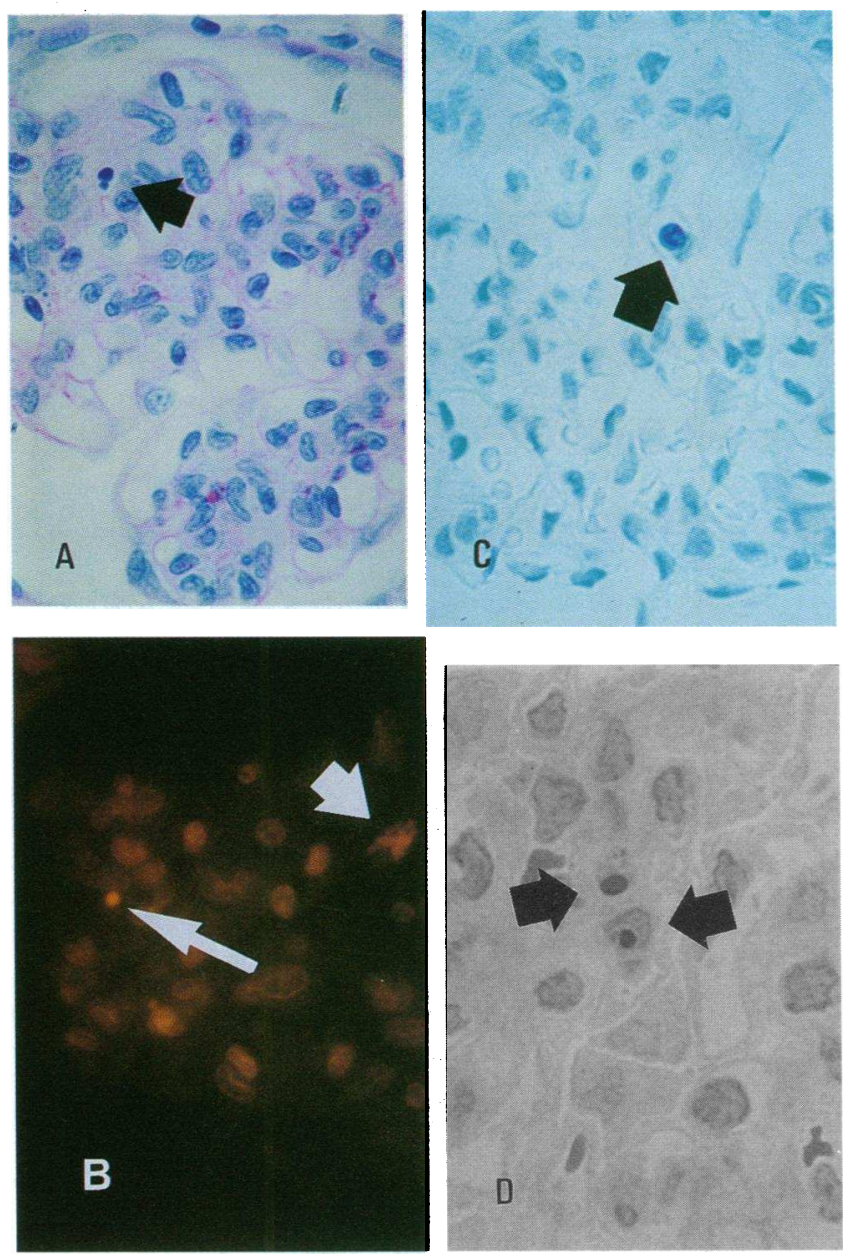

Figure 8 .

Figure 1. Light microscopy of mesangial cells detaching from growth factor-deprived culture $(\times 400)$. Note many cells have nuclear chromatin condensation and cytoplasmic condensation with vacuolation, typical light microscopical features of apoptosis (examples are arrowed). Human mesangial cell culture deprived of growth factors for $4 \mathrm{~h}$; trypan blue exclusion $>98 \%$.

Figure 4. Inverted fluorescence microscopy of mesangial cells deprived of growth factors. Acridine orange stain $(\times 200)$. A shows view in plane of cell monolayer, after $2 \mathrm{~h}$ of growth factor deprivation; a single shrunken apoptotic cell with condensed chromatin is seen (arrow). $B$ shows view in plane of medium, after $\mathbf{4 h}$ of growth factor deprivation. Three apoptotic cells are seen (arrows).

Figure 11. Coincidence of apoptosis and mitosis in same glomerulus at day 5 of Thy 1.1 nephritis. $A$ shows that mitosis and apoptosis coincided in the same glomerulus more frequently than would be predicted from percentage of glomeruli containing either an apoptosis or a mitosis. Mean $\pm S D, n=4$. $\square$, Mitoses; 0 , apoptoses; $\approx$, mitosis only; , apoptosis only; $\square$, both; and $\mathbf{m}$, predicted coincidence. $B$ is oil-immersion light micrograph of PAS-stained 4- $\mu \mathrm{m}$ section, showing apoptosis (fat arrow) and mitosis (thin arrow); note that these could not be resolved in the same focal plane, so that the apoptosis is slightly out of focus (compare with Fig. $8 \mathrm{~B}$ ). 

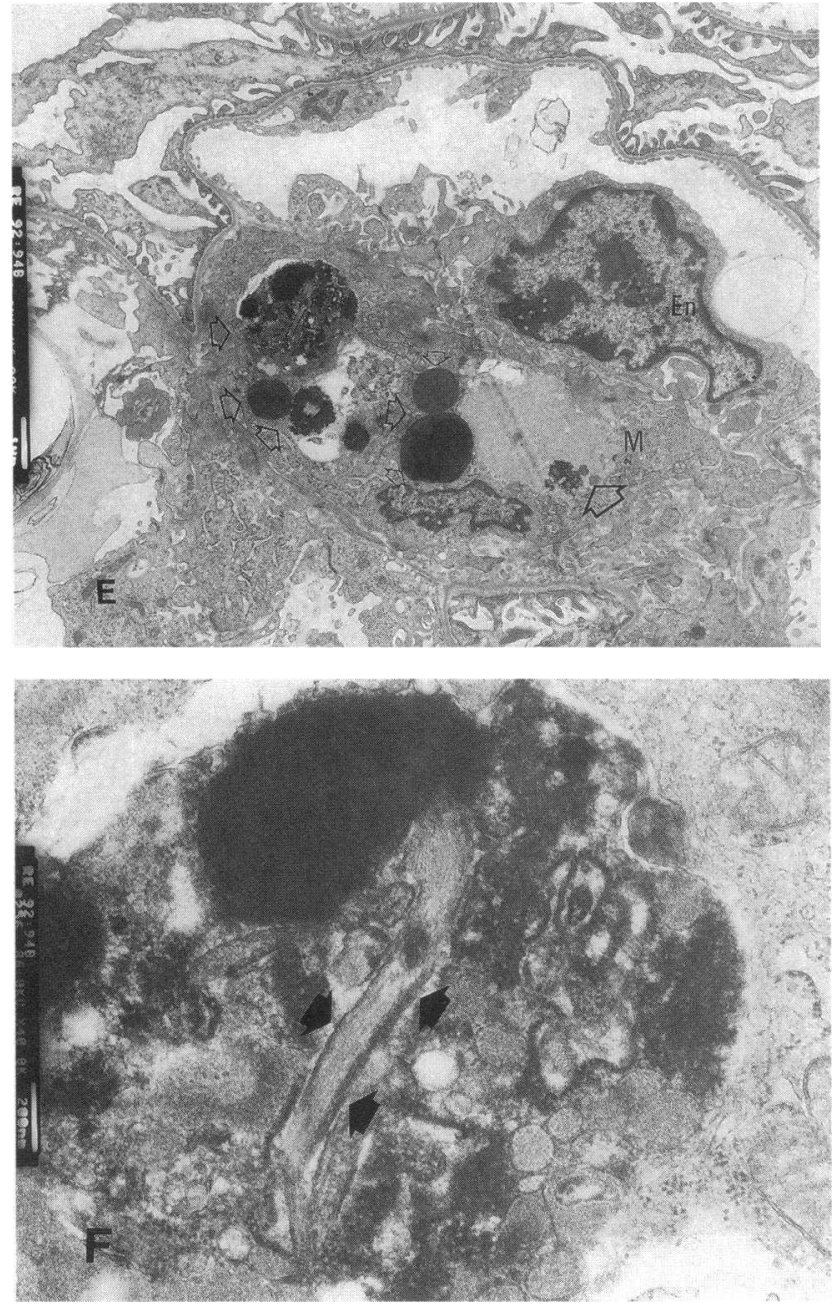

Figure 8. (Continued from preceding page) Glomerular cell apoptosis in Thy1.1 nephritis. $A$ is light microscopy $(\times 600)$ of PAS-stained sections from $14 \mathrm{~d}$. Arrowed are typical apoptotic bodies surrounded by halo, counted as a single apoptotic cell. Note mesangial position. $B$ is oil-immersion fluorescence microscopy of PI-stained section from $7 \mathrm{~d}$; note condensed nuclear chromatin (thin arrow) and mitosis (broad arrow). $C$ shows TUNEL-stained section at $5 \mathrm{~d}$; note TUNEL-positive cell within halo (arrow) in mesangial position. $D$ shows toluidine bluestained 1- $\mu \mathrm{m}$ section viewed under oil-immersion light microscopy ( $\times 600)$. Two apoptotic cells are present in the mesangium (arrows). $E$ shows EM at $5 \mathrm{~d}(\times 10,000)$. Fenestrated endothelial cell $(E n)$ can be clearly distinguished. Note mesangial cell $(M)$ containing multiple apoptotic bodies at varying stages of degradation (open arrows). $F$ is high power $(\times 50,000)$ view of ingested apoptotic cell at extreme left of $E$, demonstrating bundles of microfilaments (arrows).

Light microscopy was performed on $4-\mu \mathrm{m}$ sections of tissue fixed in methyl Carnoy's solution and paraffin embedded, stained with periodic acid-Schiff (PAS) reagent and counterstained with hematoxylin. For each animal, 50 glomerular cross-sections were counted blind for total cell number and number of apoptotic cells by oil-immersion techniques. Some sections were processed for immunoperoxidase staining as described previously $(10,25)$, using ED1 (Bioproducts for Science, Inc., Indianapolis, IN), a murine monoclonal IgG to a cytoplasmic antigen present in rat monocyte macrophages (26).

Fluorescence microscopy was performed by the same techniques on identical sections stained with propidium iodide (PI). This was done by incubating deparaffinized sections with $100 \mu \mathrm{g} / \mathrm{ml}$ RNAse in PBS at $37^{\circ} \mathrm{C}$ for $30 \mathrm{~min}$ and then with $0.25 \mathrm{mg} / \mathrm{ml} \mathrm{PI}$ in PBS for $6 \mathrm{~min}$ (14). Sections were then washed in PBS and mounted in neutral glycerin jelly.

Gavrieli et al. (27) terminal deoxynucleotidyl transferase (TdT)mediated dUTP-biotin nick end labeling (TUNEL) method for detecting DNA breaks in situ was performed as described on $4 \%$ buffered paraformaldehyde-fixed, paraffin-embedded tissue. $4-\mu \mathrm{m}$ sections were deparaffinized and incubated with proteinase $\mathrm{K} 20 \mathrm{mg} / \mathrm{ml}$ for $15 \mathrm{~min}$ at room temperature. After quenching of endogenous peroxidases, sections were rinsed in TdT buffer ( $30 \mathrm{mM}$ Tris, $140 \mathrm{mM}$ sodium cacodylate,

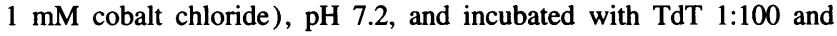
biotinylated-dUTP $1: 200$ in TdT buffer for $60 \mathrm{~min}$ at $37^{\circ} \mathrm{C}$. Labeled nuclei were detected with Vectastain $\mathrm{ABC}$ in PBS and DAB/nickel chloride/hydrogen peroxide and counterstained with methyl green.

EM was performed on tissue fixed in half-strength Karnovsky's solution, as described above.

\section{Results}

The program of apoptosis is available to cultured mesangial cells and apoptosis is increased by growth factor deprivation. In certain cell lineages, apoptosis can be triggered by deprivation of survival factors (28-31). However, in common with many cell types, mesangial cell survival factors have yet to be defined. Nevertheless, although not necessarily synonymous with survival factors, growth or mitogenic factors can in certain circumstances promote cell survival (32). Therefore, to model deprivation of survival factors, adherent cycling cultures of mesangial cells of validated purity and phenotype were deprived of growth factors. This was done by washing cells and then culturing in medium to which neither fetal calf serum nor growth supplements (such as insulin) had been added. At intervals over the next $8 \mathrm{~h}$, cells were carefully examined by inverted microscopy and some cells were seen to have rounded up, condensed, or detached from the monolayer. Upon harvesting detached cells, which were $>98 \%$ viable by trypan blue exclusion, unequivocal evidence of apoptosis was obtained in human, porcine, and rat mesangial cells.

First, such cells showed typical light microscopical features of programmed cell death when examined on May-Giemsastained cytospins (Fig. 1). Second, apoptotic cells yielded typical ladders of oligonucleosomal fragments upon electrophoresis of extracted DNA (Fig. 2). Third, apoptosis in detached cells was confirmed by EM (Fig. 3, $A$ and $B$ ). When undisturbed mesangial cell monolayers were sectioned for EM, cells in close association with the monolayer were seen undergoing apoptosis (Fig. $3 C$ ), and very occasional apoptotic cells were observed within healthy looking neighbors (Fig. $3 \mathrm{D}$ ). Furthermore, cells with typical nuclear features of apoptosis could be demonstrated in or closely associated with mesangial cell monolayers by adding acridine orange to undisturbed wells and using inverted fluorescence microscopy (Fig. $4 \mathrm{~A}$ ). Indeed, by carefully racking the objective up and down without disturbing the well, apoptotic cells could be counted in both supernatant and monolayer in the same field, enabling quantitation of apoptotic cells as a proportion of all cells (Fig. $4 \mathrm{~B}$ ).

In all growth factor-deprived cultures of mesangial cells examined, there was a progressive increase in the proportion of cells with morphology of apoptosis, reaching a mean of $\sim 10 \%$ by $8 \mathrm{~h}$ in the case of human mesangial cells (Fig. 5). In control cultures, washed and then returned to fresh medium with $10 \%$ FCS and regular growth supplements, there was a consistent background level of apoptosis (Fig. 5), which was similar in 


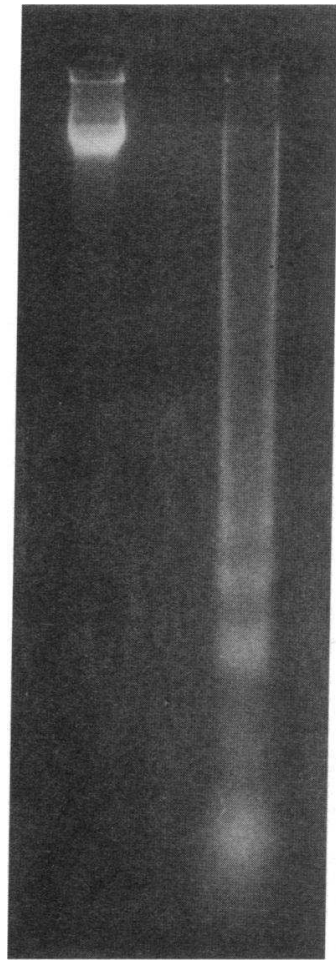

Figure 2. Chromatin cleavage in mesangial cells deprived of growth factors. Agarose gel electrophoresis of DNA extracted from porcine mesangial cells maintained in presence of growth factors (left) and deprived of growth factors for $4 \mathrm{~h}$ (right). Note oligonucleosomal fragment ladder typical of apoptosis; size markers omitted for clarity.

magnitude to that seen in undisturbed cycling cultures (data not shown). These data demonstrated that the program of apoptosis is available to cultured mesangial cells, occurring at low levels in cycling cultures, which could be increased by fastidious growth factor deprivation for $8 \mathrm{~h}$. Beyond this time, however, rigorous assessment of apoptosis became impossible because of a progressive increase in the number of swollen or disintegrating cells which failed to exclude trypan blue. It was therefore necessary to devise an alternative strategy to confirm that the program of apoptosis is available to a large proportion of mesangial cells.

Cycloheximide triggers apoptosis of cultured mesangial cells. In many cell types, the program of apoptosis may be engaged by low-grade toxic stimuli. For example, although the mechanisms of action are unknown and may therefore vary between cell types, the protein synthesis inhibitor cycloheximide can trigger apoptosis in, for example, myeloid cells (33) and Rat 1 fibroblasts (34). Cycloheximide greatly increased the proportion of growth factor-deprived mesangial cells undergoing apoptosis within $8 \mathrm{~h}$ (Fig. $6 A$ ), which was confirmed by typical chromatin cleavage (Fig. $6 \mathrm{~B}$ ), demonstrating that the program of apoptosis is available to a large proportion of cultured mesangial cells. Next we sought evidence that apoptotic cells can undergo apoptosis in vivo.

Apoptosis occurs in resolving mesangial proliferative nephritis. A pilot study of Thy1.1 nephritis in rats was undertaken (Fig. 7), in which animals were killed at time points up to 42 $\mathrm{d}$ for histological examination of their kidneys by conventional oil-immersion light microscopy of PAS-stained sections. In keeping with previous reports $(9,10)$, glomerular cell number reached a peak at $10 \mathrm{~d}$ and by $42 \mathrm{~d}$ was progressively falling toward normal. Furthermore, the number of mitotic figures peaked at $5 \mathrm{~d}$, as expected $(9,10)$. Apoptotic cells were identified by typical condensation of nuclear chromatin and cytoplasm and, as reported in many other tissues, usually appeared as a single dense body within a "halo" consistent with shrinkage and separation from surrounding cells. In some cases, a single halo contained more than one body of chromatin (Fig. $8 \mathrm{~A}$ ). Since "budding" of condensed nuclei is a well-recognized feature of apoptosis, such cells were scored as representing only one apoptotic cell. Before administration of anti-Thy1.1, glomerular cell apoptosis was very rare, occurring in $0.01 \%$ of cells. Consistent with a role in cell removal, however, apoptosis was about fivefold more frequent between days 10 and 42, a period when glomerular cell number was falling. Unexpectedly, however, the peak of apoptosis appeared to coincide with the peak of mitosis; in other models of resolution of hypercellularity it has been reported that a wave of mitosis is followed by a wave of apoptosis (35). To check this finding and confirm assignment of cells as apoptotic, a second time course experiment focusing on the first $14 \mathrm{~d}$ was performed.

Histological confirmation of apoptosis in the mesangium. In the second series of rats with Thy 1.1 nephritis, tissue was prepared to allow assessment of apoptosis by various histological techniques. There was unequivocal evidence of glomerular cell apoptosis (Fig. 8). First, light microscopical appearances were confirmed by oil-immersion fluorescence microscopy of paraffin-fixed sections stained with PI, which revealed apoptotic cells with typical homogeneous condensation of chromatin (Fig. $8 \mathrm{~B}$ ). In keeping with regular light microscopy, such cells were nearly always seen in a mesangial position and were only very rarely in capillary loops or Bowman's space. Second, TUNEL was used to detect cells with cleaved DNA (27); internucleosomal chromatin cleavage is a highly characteristic biochemical feature of apoptosis (36) which we had already demonstrated occurred in cultured mesangial cells (Fig. 2). The TUNEL technique stained shrunken cells within halos in the mesangium which appeared typical of apoptotic cells (Fig. $8 \mathrm{C}$ ), although some cells with this appearance did not show definite staining, possibly because they were in early stages of chromatin degradation. Lastly, plastic sections were examined by light and EM, which revealed typical apoptotic cells (Fig. $8 \mathrm{D}$ ). At the EM level (Fig. 8, $E$ and $F$ ) it was apparent that apoptotic cells were almost exclusively inside other cells within the mesangium, emphasizing the efficiency of phagocytic clearance. In keeping with many previous studies $(11,14,20,23)$, cytoplasmic condensation and/or degradation of ingested apoptotic cells precluded confident identification of the lineage of ingested apoptotic cells (Fig. $8 E$ ), although there were examples of ingested cells with bundles of microfilaments consistent with a mesangial cell origin (Fig. $8 \mathrm{~F}$ ).

Increased apoptosis initially correlates with mesangial cell mitosis, but persists longer. Counts of glomerular cell number, mitosis, and apoptosis were performed by light microscopy (PAS) and fluorescence microscopy (PI), yielding very similar results (Fig. 9, $A$ and $B$ ). Both techniques showed that mitosis peaked at $5 \mathrm{~d}$ and returned to normal low levels by day 14 . Total glomerular cell number steadily increased from day 3 to peak at days 7-10 before a fall first became apparent at day 14. Both techniques also showed that apoptosis was rare at time 0 and, in common with mitosis, increased to reach a peak at 5 d. Indeed, the peak frequency of apoptosis was between 5- and 10 -fold greater than in normal rat glomeruli, indicating that in the injured glomerulus there was a great increase in cell clearance by apoptosis. Moreover, unlike mitosis, apoptosis remained increased above baseline at $14 \mathrm{~d}$. To check these find- 

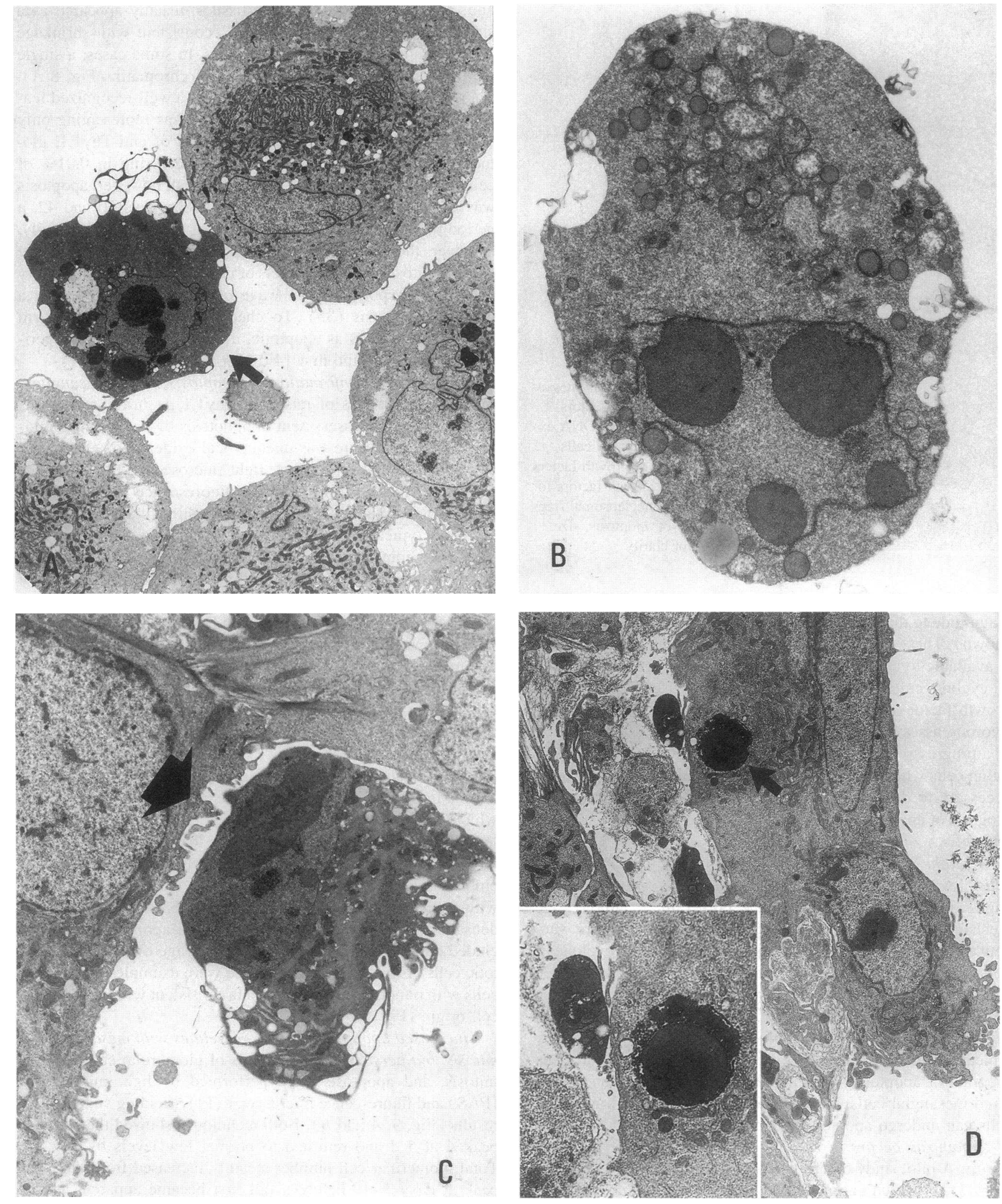

Figure 3. EM of mesangial cells deprived of growth factors. $A$ and $B$ are suspensions of cells detached from the monolayer; $C$ and $D$ are sections of adherent mesangial cell cultures. $A$ shows apoptotic cell (arrow) in close apposition to a number of detached healthy cells; note cytoplasmic condensation and vacuolation, with condensation of nuclear chromatin and fragmentation of the nucleus $(\times 1,200)$. B shows another detached mesangial cell in earlier stages of apoptosis $(\times 3,200)$. $C$ shows horizontal section through a mesangial cell culture revealing, in close association with the monolayer, a cell which is in well-established apoptosis (arrow). Note plaques of microfilaments in neighboring healthy cells $(\times 2,800)$. $D$ shows similar section through an adherent culture $(\times 1,000)$ revealing cell in advanced stages of apoptosis within a healthy mesangial cell (arrow). Inset $(\times 2,000)$ shows microfilaments cut end-on in the phagocytic cell around ingested apoptotic cell and, to left, free apoptotic body. 


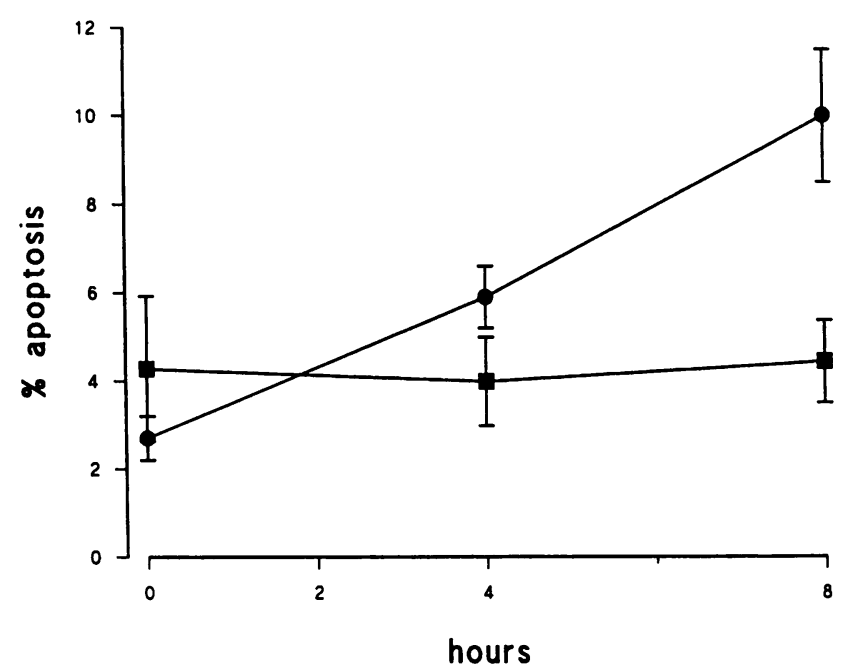

Figure 5. Time course of apoptosis in mesangial cells deprived of growth factors. Cells washed at time 0 and then deprived of growth factors by being maintained in RPMI alone (closed circles) show progressively increasing apoptosis. Cells washed at time 0 and then returned to RPMI medium plus $10 \%$ FCS plus growth supplements (closed squares) show consistent level of apoptosis. Human mesangial cells. Mean $\pm S D, n=6$.

ings, TUNEL was performed at a limited number of time points (Fig. 10) and confirmed persistent elevation of apoptosis above baseline at $14 \mathrm{~d}$ and a peak at $5 \mathrm{~d} \sim 10$-fold greater than at 0 $h$. However, the absolute number of TUNEL-positive cells was consistently lower than that counted by light or fluorescence microscopy (as alluded to above, there was evidence that, in the tissue we studied, TUNEL was less sensitive for detection of apoptotic cells than microscopic techniques). Thus the coincidence of the peaks of apoptosis and mitosis observed in the pilot study (Fig. 7) was confirmed. Indeed, the coordinated nature of these events was emphasized by the observation that apoptosis and mitosis coincided in the same glomerulus more frequently than would be predicted by chance alone (Fig. 11 $A$ ), not less frequently as would have occurred if there were subpopulations of glomeruli in which conditions favored either apoptosis or mitosis but not both. Indeed, apoptotic cells and mitotic figures were often seen in very close spatial association (Fig. $11 B$, and see also Fig. $8 B$ ).

Changes in the ratio of apoptosis to mitosis are commensurate with changes in cell number. From days 3 to 7 inclusive, during which time glomerular cell number increased, it is readily appreciated from Fig. 9 that mitosis was about twofold more frequent than apoptosis (e.g., at $5 \mathrm{~d}, 16.8 \pm 2.9$ [mean $\pm \mathrm{SD}$, $n=4$ ] mitoses and $8.3 \pm 4.3$ apoptoses per 50 glomerular crosssections were observed by PAS staining, while the figures were $18.5 \pm 4$ mitoses and $11.0 \pm 1.4$ apoptoses by PI). Although some of the increase in glomerular cell number reflected infiltration by leukocytes (the vast majority of which were macrophages), Table I demonstrates that this only represented a small proportion of the total increase in glomerular cell number, which previous studies have shown is predominantly accounted for by mesangial cell proliferation $(10,25,37-40)$. Furthermore, at days 10 and 14, between which glomerular cell number fell, apoptosis was seen more frequently than mitosis. Indeed, not only did cell number decline at a rate similar to that at which it had increased between days 3 and 7, but also the disparity in fre-
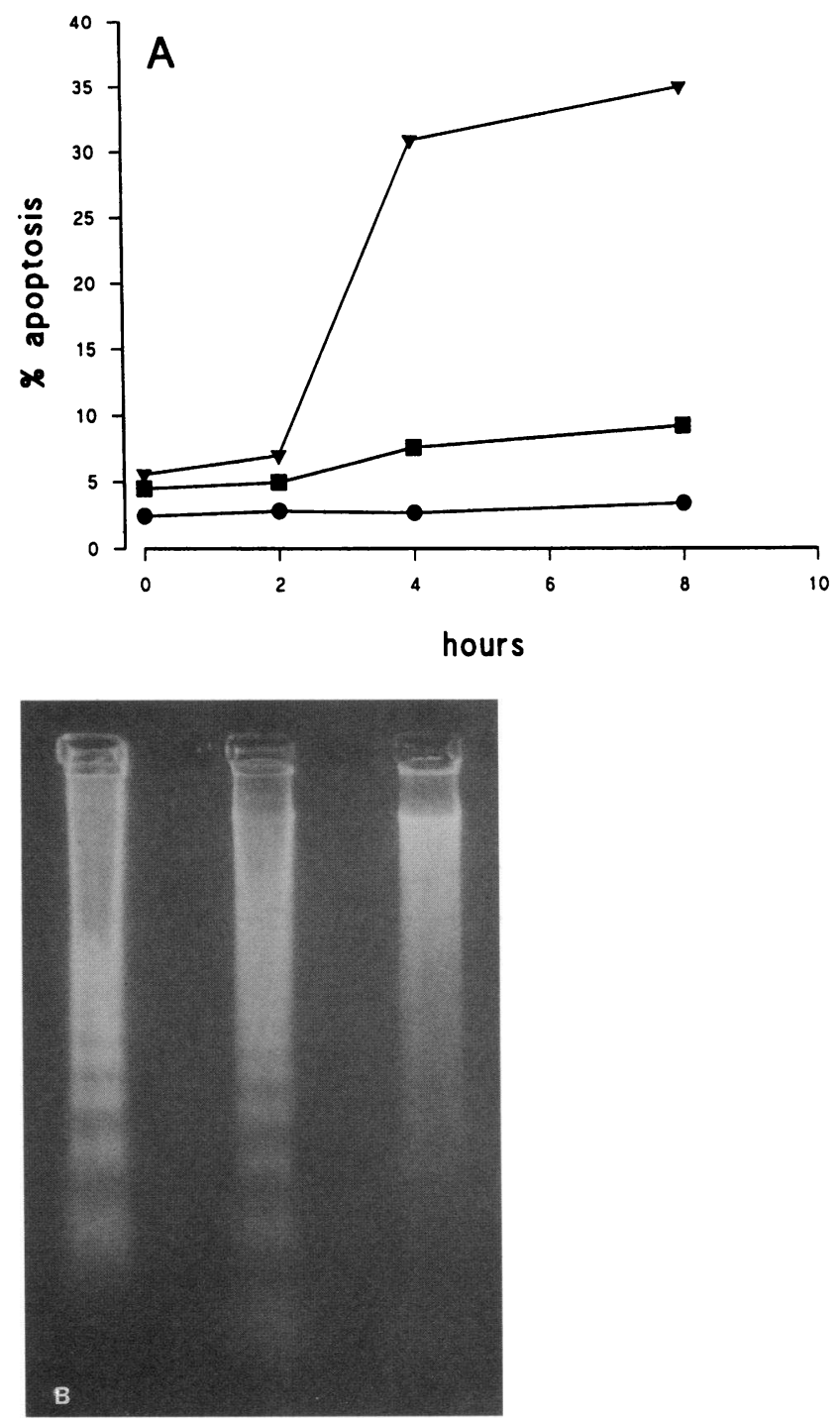

Figure 6. Effect of cycloheximide on apoptosis in mesangial cells deprived of growth factors. $(A)$ Time course: porcine mesangial cells washed at time 0 and then maintained in RPMI alone (closed squares), RPMI plus $50 \mu \mathrm{M}$ cycloheximide (closed triangles), and RPMI medium with $10 \%$ FCS and growth supplements (closed circles). Note potentiating effect of cycloheximide in this typical experiment. $(B)$ Biochemical confirmation of apoptosis: agarose gel electrophoresis of DNA extracted from apoptotic human neutrophils (left), used as a control, human mesangial cells (center), and rat mesangial cells (right) cultured for $4 \mathrm{~h}$ in the presence of $50 \mu \mathrm{M}$ cycloheximide.

quencies of apoptosis and mitosis was similar in magnitude but reversed, so that apoptosis was detected about twofold more frequently than mitosis (e.g., at $14 \mathrm{~d}$, PAS staining only detected $2.8 \pm 2.8$ mitoses as opposed to $5.0 \pm 1.4$ apoptoses per 50 glomerular cross-sections, while by PI the figures were $1.5 \pm 1.6$ mitoses and $4.5 \pm 2.6$ apoptoses).

\section{Discussion}

In this study we have examined the hitherto obscure mechanisms by which surplus mesangial cells are cleared from glomeruli during resolution of mesangial proliferative nephritis. 

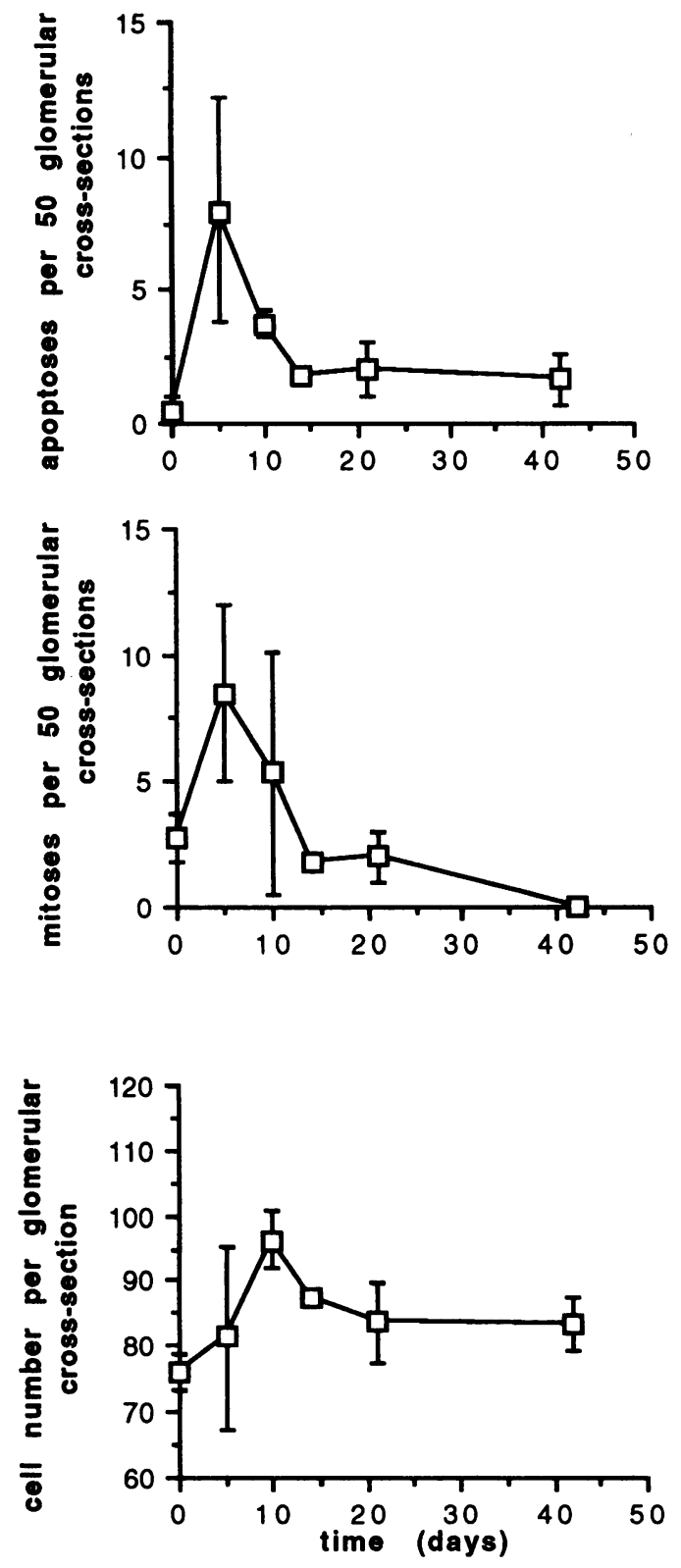

Figure 7. Histological time course study of Thy1.1 nephritis in rats. Cell number per glomerular cross-section (bottom), and mitotic figures (center) and apoptotic cells (top) per 50 glomerular cross-sections. Oilimmersion light microscopy of PAS-stained material; antibody administered at day 0 . See text for further description. Mean $\pm S D, n=4$ at each time point.

Mesangial cell clearance is important to understand because undesirable accumulation of mesangial cells can herald glomerular scarring. Our data show that mesangial cells can undergo apoptosis. In culture, cycling cells exhibit a low frequency of apoptosis which can be increased by growth factor deprivation and cycloheximide, stimuli well known to induce apoptosis in other cell types. Furthermore, when compared with normal rat glomeruli, apoptosis occurs with greatly increased frequency in the mesangium in the rat Thy 1.1 model of self-limited mesangial proliferation, where it leads to efficient phagocytosis of apoptotic cells by neighboring mesangial cells. The observed changes in frequency of apoptosis strongly suggest that, in glo- meruli mounting a mesangial proliferative response to injury, apoptosis is the major cell clearance mechanism counterbalancing cell accumulation due to increased mitosis, thereby mediating resolution of glomerular hypercellularity.

The glomerulus is a discrete structure consisting of only three cell types and, therefore, offers special opportunities to gain insights into mechanisms underlying persistent inflammation and scarring, which cause irreversible loss of function of not only the kidney but also other vital organs. A large body of work has suggested that the specialized pericyte of the glomerulus, the mesangial cell, may play a crucial role in glomerular scarring because this cell type can summon leukocytes by secretion of proinflammatory cytokines and disrupt glomerular structure by excessive secretion of extracellular matrix (1-4, 41 ). Increased numbers of mesangial cells occur in many forms of glomerular disease before scarring ensues, and, since it is widely believed that this is a key event in glomerular scarring, great efforts have been made to define mechanisms by which mesangial cells proliferate (1-4). However, mechanisms which may counterbalance mesangial cell accumulation have received remarkably little attention, even though resolution of mesangial proliferation (the commonly used pathological term for increased mesangial cell number) is a well-recognized clinical phenomenon (8). The major conclusion of this study is that clearance of surplus mesangial cells from the glomerulus can be mediated by apoptosis, a programmed form of cell death subject to external regulation.

First, we found that cultured mesangial cells can undergo apoptosis. This was despite a large body of previous work which emphasized that these cells may elaborate autocrine and paracrine growth factors and, perhaps as a consequence, may endure prolonged periods of growth factor deprivation in vitro in a quiescent state (for review see references 1 and 4). Notably, in many studies this state was achieved by including a low concentration of serum or plasma in medium, or including insulin $(1,4)$. In our experiments these potential survival factors were rigorously excluded, and by $8 \mathrm{~h}$ up to $10 \%$ of human mesangial cells had undergone apoptosis. After this time, detached apoptotic cells began to disintegrate, precluding accurate quantification of apoptosis in undisturbed cultures. However, a high proportion of starved mesangial cells appeared to remain viable at $24 \mathrm{~h}$, and others have observed that mesangial cell cultures without any added growth factors can survive for a few days without extensive loss of cells (Resch, K., personal communication). The possibility that cultured mesangial cells may be making proteins which keep themselves (or a high proportion of neighbors) alive was supported by our observation that the protein synthesis inhibitor cycloheximide was able to trigger apoptosis in a much greater proportion of cells than growth factor deprivation alone. However, although interrupted supply of a putative autocrine survival protein might be one mechanism by which cycloheximide can induce apoptosis in other cell types such as HL60 cells (33), there are other potential mechanisms including a direct toxic effect. Nevertheless, future studies will need to define whether quiescent mesangial cells synthesize proteins protecting themselves or neighbors against apoptosis induced by deprivation of survival factors.

Second, we demonstrated the in vivo relevance of these findings in Thy1.1 nephritis, a valuable model of self-limited and selective proliferation of mesangial cells in which crucial insights into the pathogenesis of glomerular scarring have already been obtained $(6,10,25,37-40,42)$. Administration of 

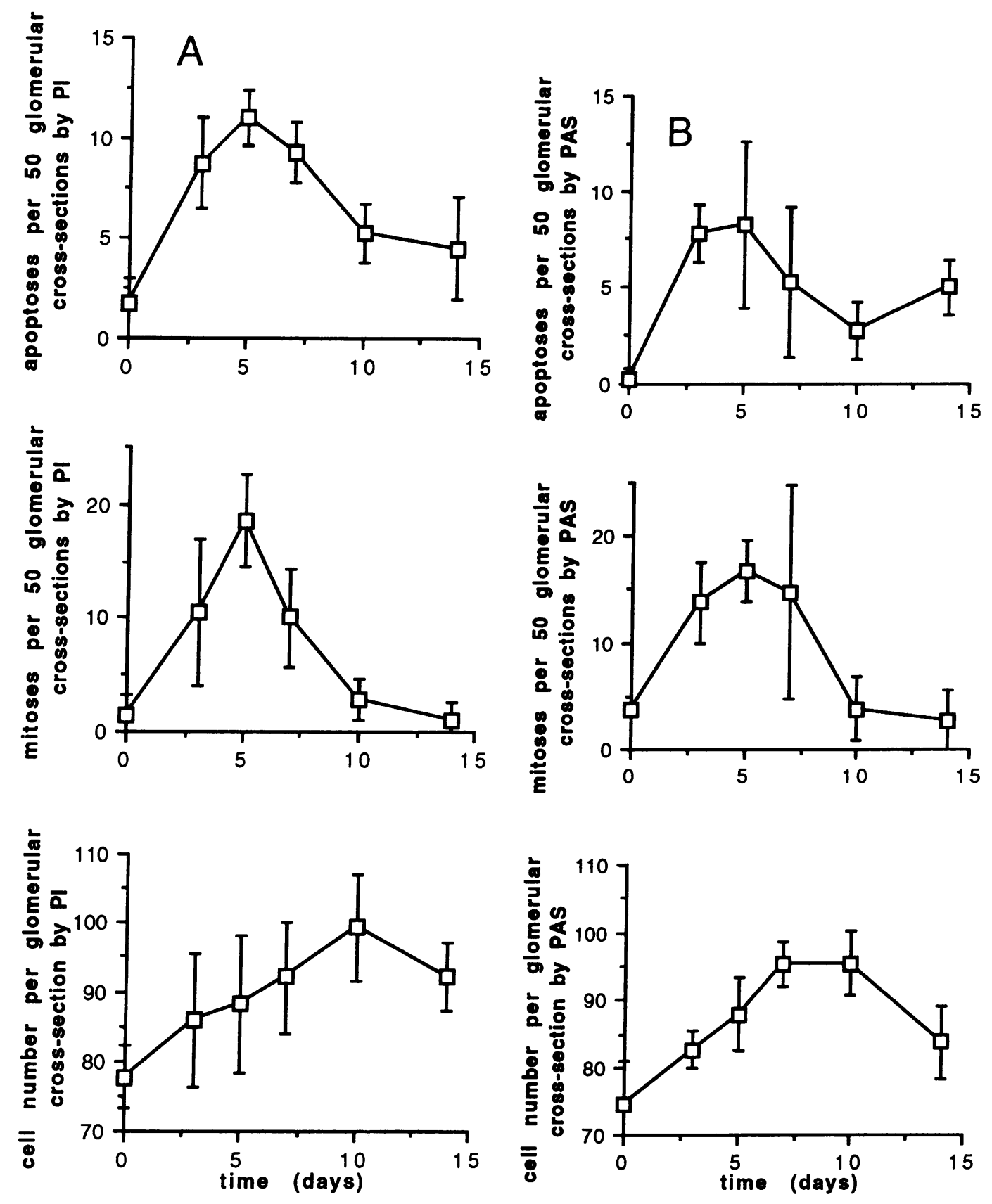

Figure 9. Histological time course study of Thy1.1 nephritis in rats. Cell number per glomerular cross-section (lower panels), mitotic figures (middle panels) and apoptotic cells (upper panels) per 50 glomerular cross-sections. $A$ is PI-stained material and $B$ is PAS-stained material. See text for further description. Mean $\pm \mathrm{SD}, n=4$ at each time point.

antibody to Thy1.1, which is expressed by mesangial cells in the rat, causes a brisk mesangiolysis, which is rapidly followed by rebound mesangial proliferation. The number of mesangial cells progressively rises from a nadir of $\sim 1$ per glomerular cross-section to reach a peak at $10-14 \mathrm{~d}$, when mesangial cell number is about double normal. Mesangial cell number then gradually returns to baseline, but the mechanisms responsible have been obscure. However, in this condition (as in many types of human glomerulonephritis) mesangial cells in diseased glomeruli assume a phenotype similar to that in culture, with features of the myofibroblast of skin wounds $(18,19,37,43)$. This suggested that in Thy 1.1 nephritis surplus mesangial cells might be cleared by apoptosis because there is morphological evidence of myofibroblast apoptosis in resolving skin wounds (43) and because we had found that cultured myofibroblastlike mesangial cells could undergo apoptosis. Light microscopy of both PAS-stained paraffin sections and toluidine bluestained plastic sections, fluorescence microscopy of PI-stained paraffin sections, transmission EM, and terminal transferase labeling of DNA cleaved as a consequence of the endonuclease activity of apoptosis all revealed unequivocal evidence of mesangial apoptosis in Thy1.1 nephritis. Although there was some variability in the absolute number of apoptotic cells detected in different sections of healthy rat kidney by the three light 


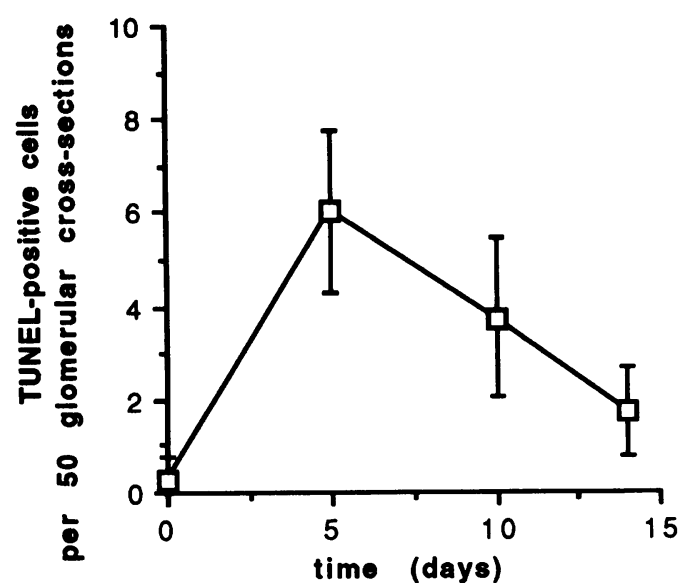

Figure 10. Time course study of TUNEL-positive cells in Thy1.1 nephritis in rats. See text for further description. Mean $\pm S D, n=4$ at each time point.

microscopical techniques, it should be noted that there were dramatic increases (i.e., 10-fold) in the number of apoptotic cells during the course of the glomerular response to injury by Thy 1.1 antibody. Furthermore, in keeping with many previous studies $(11,14,20,23)$, EM studies showed that the vast majority of apoptotic cells had already been taken up by neighboring cells, emphasizing the speed and efficiency of this mode of cell clearance. Therefore, it is apparent that in this model of the glomerular proliferative response to injury there is a considerable increase in cell clearance by apoptosis when compared with the normal glomerulus.

Indeed, the relationship between $(a)$ the ratio of apoptosis to mitosis and $(b)$ changes in glomerular cell number strongly suggests that apoptosis is the major mechanism by which excess glomerular cells are cleared during resolution of glomerular hypercellularity in Thy 1.1 nephritis. Thus mitosis exceeded apoptosis by up to twofold when cell number was increasing between days 3 and 7 . However, when cell number was decreasing at an approximately similar rate between days 10 and 14 , apoptosis exceeded mitosis by approximately the same degree. Caution is required in interpretation of these data, since the visible portions of the programs of apoptosis and mitosis only represent a small proportion of the time it takes to trigger and complete cell division or cell death, in each case being detectable by conventional histology for $0.5-2.0 \mathrm{~h}(11,14-16,44-$ 46). However, if some process other than apoptosis, for example cell emigration, were responsible for clearance of the majority of glomerular cells, then this pattern should not have been seen; one would not expect apoptosis to be more common than mitosis as cell number fell. Cell emigration may be important in clearance of macrophages from inflamed glomeruli (47), but these cells make only a small contribution to the total increase in glomerular cell number. Therefore, because an appropriate relationship between apoptosis, mitosis, and cell number was retained during the course of Thy 1.1 nephritis, we feel it is reasonable to propose that apoptosis is the major cell clearance mechanism counterbalancing mitosis and that no other process assumes a major role in cell clearance from the hypercellular glomerulus in Thy1.1 nephritis.

The data also strongly suggest that the majority of cells undergoing apoptosis in Thy1.1 nephritis are mesangial cells.
Table I. Increase in Glomerular Cell Number during the Course of Thy1.1 Nephritis: Small Contribution of the Major Infiltrating Leukocyte Population, Macrophages

\begin{tabular}{ccc}
\hline Time point & $\begin{array}{c}\text { Glomerular } \\
\text { macrophages }\end{array}$ & Total glomerular cells \\
\hline & $\begin{array}{c}\text { ED-1-positive cells per } \\
\text { glomerular cross-section }\end{array}$ & per glomerular cross-section \\
$0 \mathrm{~h}$ & $2.3 \pm 0.1$ & $77.7 \pm 4.5$ \\
$8 \mathrm{~h}$ & $6.7 \pm 1.2$ & $58.7 \pm 3.2$ \\
$3 \mathrm{~d}$ & $9.3 \pm 2.6$ & $85.7 \pm 9.6$ \\
$5 \mathrm{~d}$ & $8.7 \pm 1.2$ & $88.4 \pm 10.0$ \\
$7 \mathrm{~d}$ & $7.5 \pm 1.8$ & $92.0 \pm 8.2$ \\
$10 \mathrm{~d}$ & $6.3 \pm 0.9$ & $99.3 \pm 7.8$ \\
$14 \mathrm{~d}$ & $4.2 \pm 1.0$ & $92.1 \pm 5.0$ \\
\hline
\end{tabular}

Data are mean $\pm \mathrm{SD}, n=4$. Note that macrophages constitute only a small proportion of the increase in glomerular cell number, whether taken from time 0 or the nadir at $8 \mathrm{~h}$, when mesangiolysis has occurred.

It should be appreciated that, except in circumstances where cells undergoing apoptosis have distinguishing cytoplasmic features such as neutrophil granules (23), it can be virtually impossible to determine the lineage of a cell undergoing apoptosis. This is because the highly reproducible morphological changes of apoptosis yield shrunken cells of sterotyped appearance and because apoptotic cells are rapidly ingested and degraded by neighboring phagocytes (11). Furthermore, what might appear to be the cytoplasm of an apoptotic cell at the light microscopical level is often revealed by EM to be the cytoplasm of a phagocytic cell which has engulfed a neighbor, rendering light microscopical double staining approaches an unreliable way of defining the cell type undergoing apoptosis. Indeed, the lineage of apoptotic cells in vivo is nearly always inferred by knowledge of their position, the known composition and kinetics of cell populations at that site, and whether the suspected cell type is known to undergo apoptosis when in pure culture (11). According to these criteria, it appeared most likely that the vast majority of apoptotic cells in Thy 1.1 nephritis were derived from mesangial cells. First, apart from occasional examples, apoptotic cells occupied a mesangial position when examined by the technique with greatest spatial resolution, EM. Furthermore, there were examples of ingested apoptotic cells in early stages of degradation which appeared to contain bundles of microfilaments consistent with a mesangial cell origin. Second, it is well established that in Thy1.1 nephritis the vast majority of proliferating cells $(>85 \%)$ express the Thy 1.1 antigen, indicating that they are mesangial cells $(10,25,37-40)$. This suggests that much the most major clearance task is reduction of expanded numbers of mesangial cells rather than other types of cell, particularly as most Thy1.1-negative proliferating cells have been identified previously as macrophages $(10,25,37-$ 40 ), which may leave the glomerulus to meet their fate elsewhere (47). Low-grade endothelial cell proliferation probably does occur in Thy1.1 nephritis (Johnson, R. J., unpublished observations), but at most makes a very minor contribution to the burden of glomerular cells requiring clearance. Third, we showed that cultured mesangial cells, thought to be representative models of the mesangial cells of diseased glomeruli, underwent apoptosis in culture. To summarize, we feel that it is 
reasonable to conclude that the majority of cells undergoing apoptosis in the Thy1.1 model are mesangial cells.

The mechanisms underlying regulation of mesangial cell apoptosis in Thy1.1 nephritis are likely to be complex. Mesangial cell apoptosis triggered by deprivation of growth factors, as in culture, seems unlikely to be occurring in the growth factor-rich microenvironment of the injured glomerlus in Thy1.1 nephritis. However, it is possible that deficiency of yet to be characterized mesangial cell survival factors could play a role if mesangial cell growth factors prove in future studies to be weak survival factors, since it is believed that proliferating cells may be particularly susceptible to undergoing apoptosis should survival factors be in short supply $(28,34)$. However, it seems likely that other factors are involved in triggering mesangial cell apoptosis. These could include homeostatic death factors as implicated in Polunovsky and colleagues' (48) study of resolving fibroblastic granulation tissue in the lung. Ongoing studies will address these issues and will need to take care in comparision of in vitro and in vivo data.

Finally, the current data need to be set in the context of what is already known of apoptosis in the kidney. Building on our earlier finding that neutrophils are eliminated from inflamed sites by apoptosis leading to specific recognition by macrophages $(23,49,50)$, we demonstrated that this leukocyte clearance mechanism operates in the glomerulus (20), but we did not examine clearance of resident glomerular cells. However, apoptosis has been implicated before as a homeostatic mechanism mediating removal of excess resident kidney cells, although this was in regression of tubular rather than glomerular hyperplasia (35). Some similarity in the mechanisms involved may be inferred from preliminary reports that both murine tubular cells and mesangial cells can express various genes known to regulate apoptosis $(51,52)$, important data which will require detailed examination in the future. Furthermore, since tubular cell apoptosis can be induced by injurious stimuli such as ischemia (53), it is important to note that injury may be one of a number of triggers to mesangial cell apoptosis. Indeed, although the principle mode of mesangial cell injury in the first few hours of Thy1.1 nephritis appears to be antibody- and complementmediated lysis, occasional apoptotic mesangial cells were seen, presumably reflecting cells undergoing apoptosis as a response to low-grade injury (9). This emphasizes that the program of apoptosis may be engaged in ways which are not always beneficial for the health of the glomerulus. Nevertheless, our data suggest that in mesangial cells the program of apoptosis can also be engaged as a homeostatic mechanism controlling the size of the glomerular mesangial cell population and promoting resolution of the mesangial proliferative response to injury. Furthermore, since glomerular epithelial and endothelial proliferation can resolve in human disease, and because these cell types can be deleted by apoptosis in other organs $(11,48)$, future studies of glomerular cell apoptosis should also examine control of epithelial and endothelial population size by this mode of cell death.

To conclude, we report in vitro and in vivo evidence indicating that the program of apoptosis is available to mesangial cells. This program may be engaged to limit increases in mesangial cell number in the face of a proliferative stimulus and to mediate removal of surplus mesangial cells once such a stimulus has passed. We speculate that failure to clear excess cells by apoptosis, perhaps due to local conditions promoting survival, could be a hitherto unrecognized factor in the pathogenesis of persistent mesangial cell hyperplasia and thus glomerular scarring. Indeed, future studies of control of apoptosis in the mesangial cell may not only shed light on this problem, but also might yield new therapeutic approaches toward glomerular disease designed to harness the power of apoptosis to clear away unwanted glomerular cells without serious disruption of structure or function.

\section{Acknowledgments}

The invaluable assistance of Dr. D. Hockenbery and colleagues (Department of Medicine, University of Seattle, Seattle, WA) with TUNEL is gratefully acknowledged, as is the expert help with histology and EM given by Professor D. R. Turner and Mr. Trevor Gray (Department of Pathology, University of Nottingham). We are also grateful for the continuing advice of Professor C. Haslett (University of Edinburgh, Scotland) and Professor A. J. Rees (Royal Postgraduate Medical School, London).

A. Mooney and J. Hughes are Medical Research Council Training Fellows, and J. Savill formerly held a Wellcome Trust Senior Research Fellowship in Clinical Science. A. J. Baker has been supported by the Wellcome Trust, which funded experiments through grants 035283 and 013158. Work was also supported by National Institutes of Health (NIH) grants DK-43422 and DK-02142 and an NIH George M. O'Brien Kidney Center grant.

\section{References}

1. Lovett, D. H., and R. B. Sterzel. 1986. Cell culture approaches to the analysis of glomerular inflammation. Kidney Int. 30:246-254.

2. Striker, L. J., E. P. Peten, S. J. Elliot, T. Doi, and G. E. Striker. 1991 Mesangial cell turnover: effect of heparin and peptide growth factors. Lab. Invest. 64:446-456

3. Mene, P., M. S. Simonson, and M. J. Dunn. 1989. Physiology of the mesangial cell. Physiol. Rev. 69:1374-1424.

4. Abboud, H. E. 1993. Nephrology forum: growth factors in glomerulonephritis. Kidney Int.43:252-267.

5. Schulz, P. J., P. E. Di Corleto, B. J. Silver, and H. E. Abboud. 1988 Mesangial cells express PDGF mRNAs and proliferate in response to PDGF. Am. J. Physiol. 255:F674-F679.

6. Johnson, R. J., E. W. Raines, J. Floege, A. Yoshimura, P. Pritzl, C. Alpers, and R. Ross. 1992. Inhibition of mesangial cell proliferation and matrix expansion in glomerulonephritis in the rat by antibody to platelet-derived growth factor. $J$. Exp. Med. 175:1413-1416.

7. Isaka, Y., Y. Fujiwara, N. Ueda, Y. Kaneda, T. Kamada, and E. Imai. 1993. Glomerulosclerosis induced by in vivo transfection of transforming growth factor$\beta$ or platelet-derived growth factor gene into the rat kidney. J. Clin. Invest. 92:2597-2601.

8. Cameron, J. S. 1993. Long-term outcome of glomerular diseases. In Diseases of the Kidney. 5th ed. R. W. Schrier and C. W. Gottschalk, editors. Little, Brown and Co., Boston. 1895-1958.

9. Bagchus, W. M., P.-J. Hoedemaeker, J. Rozing, and W. W. Bakker. 1986. Glomerulonephritis induced by monoclonal anti-Thy1.1 antibodies. A sequential histological and ultrastructural study in the rat. Lab. Invest. 55:680-687.

10. Johnson, R. J., R. L. Garcia, P. Pritzl, and C. E. Alpers. 1990. Platelets mediate glomerular cell proliferation induced by anti-mesangial cell antibodies in the rat. Am. J. Pathol. 136:369-374.

11. Wyllie, A. H., J. F. R. Kerr, and A. R. Currie. 1980. Cell death: the significance of apoptosis. Int. Rev. Cytol. 68:251-306.

12. Cohen, J. J. 1991. Programmed cell death in immune system. Adv. Immunol. 50:55-85.

13. Williams, G. T., and C. A. Smith, 1993. Molecular regulation of apoptosis: genetic controls on cell death. Cell. 74:777-779.

14. Coles, H. S. R., J. F. Burne, and M. C. Raff. 1993. Large-scale normal cell death in the developing rat kidney and its reduction by epidermal growth factor. Development (Camb.). 118:777-784.

15. Perry, V. H., Z. Henderson, and R. Linden. 1983. Postnatal changes in retinal ganglion cell and optic axon populations in pigmented rat. J. Comp. Neurol. 219:356-368.

16. Ellis, R. E., J. Yuan, and H. R. Horvitz. 1991. Mechanisms and functions of cell death. Annu. Rev. Cell Biol. 7:663-698.

17. Harrison, D. J. 1988. Cell death in the diseased glomerulus. Histopathology (Oxf.). 12:679-683. 
18. Johnson, R. J., J. Floege, A. Yoshimura, H. Iida, W. G. Couser, and C. E. Alpers. 1992. The activated mesangial cell: a glomerular "myofibroblast?" $J$. Am. Soc. Nephrol. 2:S190-S197.

19. Alpers, C. E., K. L. Hudkins, A. M. Gown, and R. J. Johnson. 1992 Enhanced expression of muscle-specific actin in glomerulonephritis. Kidney Int 41:1134-1142.

20. Savill, J. S., J. Smith, Y. Ren, C. Sarraf, F. Abbott, and A. J. Rees. 1992. Glomerular mesangial cells and inflammatory macrophages ingest neutrophils undergoing apoptosis. Kidney Int. 42:924-936.

21. Abbot, F., J. Ryan, M. Ceska, K. Matsushima, C. Sarraf, and A. J. Rees 1991. Interleukin-1B stimulates human mesangial cells to synthesise interleukins6 and -8. Kidney Int. 40:597-605.

22. Arends, M. J., R. G. Morris, and A. H. Wyllie. 1990. Apoptosis: the role of the endonuclease. Am. J. Pathol. 136:593-608.

23. Savill, J. S., A. H. Wyllie, J. E. Henson, M. J. Walport, P. M. Henson, and C. Haslett. 1989. Macrophage phagocytosis of aging neutrophils in inflammation. Programmed cell death in the neutrophil leads to its recognition by macrophages. J. Clin. Invest. 83:865-875.

24. Whyte, M. K. B., S. J. Hardwick, L. C. Meagher, J. S. Savill, and C Haslett. 1993. Transient elevations of cytosolic free calcium retard subsequen apoptosis in neutrophils in vitro. J. Clin. Invest. 92:446-455.

25. Johnson, R. J., H. Iida, P. Pritzl, and C. E. Alpers. 1990. Platelet-complement interactions in mesangial proliferature nephritis in the rat. Am J. Pathol. 138:313-322.

26. Dijkstra, C. D., E. A. Dopp, P. Joling, and G. Kraal. 1985. The heterogeneity of mononuclear phagocytes in lymphoid organs: distinct macrophage popula tion in the rat recognized by monoclonal antibodies ED1 ED2 and ED3. Immunology. 54:589-599.

27. Gavrieli, Y., Y. Sherman, and S. A. Ben-Sasson. 1992. Identification of programmed cell death in situ via specific labeling of nuclear DNA fragmentation. J. Cell Biol. 119:493-501.

28. Raff, M. C. 1992. Social controls on cell survival and cell death. Nature (Lond.). 356:397-400.

29. Duke, R. C., and J. J. Cohen. 1986. IL-2 addiction: withdrawal of growth factor activates a suicide program in dependent T cells. Lymphokine Res. 5:289294.

30. Sendtner, M., G. W. Kreuzberg, and H. Thoenen. 1990. Ciliary neurotrophic factor prevents the degeneration of motor neurons after axotomy. Nature (Lond.). 345:440-442.

31. Koury, M. J., and M. C. Bondurant. 1990. Erythropoietin retards DNA breakdown and prevents programmed death in erythoid progenitor cells. Science (Wash. DC). 246:378-380.

32. Barres, B. A., I. K. Hart, H. S. R. Coles, J. F. Burne, J. T. Voyvodic W. D. Richardson, and M. C. Raff. 1992. Cell death and control of cell survival in the oligodendrocyte lineage. Cell. 70:31-46.

33. Martin, S. J., S. V. Lennon, A. M. Bonham, and T. G. Cotter. 1990 Induction of apoptosis (programmed cell death) in human leukaemic HL-60 cells by inhibition of RNA or protein synthesis. J. Immunol. 145:1859-1867.

34. Evan, G. I., A. H. Wyllie, C. S. Gilbert, T. D. Littlewood, H. Land, M. Brooks, C. M. Waters, L. Z. Penn, and D. C. Hancock. 1992. Induction of apoptosis in fibroblasts by c-myc protein. Cell. 69:119-128.

35. Ledda-Columbano, G. M., A. Columbano, P. Coni, G. Faa, and P. Pani.
1989. Cell deletion by apoptosis during regression of renal hyperplasia. Am. $J$. Pathol. 135:657-662.

36. Wyllie, A. H. 1980. Glucocorticoid-induced thymocyte apoptosis is associated with endogenous endonuclease activation. Nature (Lond.). 284:555-556.

37. Johnson, R. J., H. Iida, C. E. Alpers, M. W. Majesley, S. M. Schwartz, P. Pritzl, K. Gordon, and A. M. Gown. 1991. Expression of smooth muscle cell phenotype by rat mesangial cells in immune complex nephritis. J. Clin. Invest. 87:847-858

38. Iida, H., R. Seifert, C. E. Alpers, R. G. K. Gronwald, P. E. Phillips, P. Pritzl, K. Gordon, A. M. Gown, R. Ross, D. E. Bowen-Pope, and R. J. Johnson. 1991. Platelet-derived growth factor (PDGF) and PDGF receptor are induced in mesangial proliferative nephritis in the rat. Proc. Natl. Acad. Sci. USA. 88:65606564.

39. Floege, J., R. J. Johnson, K. Gordon, H. Iida, P. Pritzl, A. Yoshimura, C. Campbell, and W. G. Couser. 1991. Increased synthesis of extracellular matrix in mesangial proliferative nephritis. Kidney Int. 40:477-488.

40. Floege, J., E. Eng, B. A. Young, W. G. Couser, and R. J. Johnson. 1993. Heparin suppresses mesangial cell proliferation and matrix expansion in experimental mesangial proliferative nephritis. Kidney Int. 43:369-380.

41. Border, W. A., and E. Ruoslahti. 1992. Transforming growth factor- $\beta$ in disease: the dark side of tissue repair. J. Clin. Invest. 90:1-7.

42. Border, W. A., S. Okuda, L. R. Languino, M. B. Sporn, and E. Ruoslahti. 1990. Suppression of experimental glomerulonephritis by antiserum against growth factor- $\beta$. Nature (Lond.). 346:371-374.

43. Darby, I., O. Skalli, and G. Gabbiani. 1990. Alpha-smooth muscle actin is transiently expressed by myofibroblasts during wound healing. Lab. Invest. 63:21-29.

44. Pabst, R., and R. B. Sterzel. 1983. Cell renewal of glomerular cell types in normal rats. An autoradiographic analysis. Kidney Int. 24:626-631.

45. Cell growth and division. In Molecular Biology of the Cell. 1983. B. Alberts, D. Bray, J. Lewis, M. Raff, K. Roberts, and J. D. Watson, editors. Garland Publishing Inc., New York. 611-671.

46. Avers, C. J. 1976. Mitosis and Meiosis. D. Van Nostrand Co., New York. 449-503.

47. Lan, H. Y., D. J. Nikolic-Paterson, and R. C. Atkins. 1993. Trafficking of inflammatory macrophages from the kidney to draining lymph nodes during experimental glomerulonephritis. Clin. Exp. Immunol. 92:336-341.

48. Polunovsky, V. A., B. Chen, C. Henke, D. Snover, C. Wendt, D. H. Ingbar, and P. B. Bitterman. 1993. Role of mesenchymal cell death in lung remodeling after injury. J. Clin. Invest. 92:388-397.

49. Savill, J., I. Dransfield, N. Hogg, and C. Haslett. 1990. Vitronectin receptor mediated phagocytosis of cells undergoing apoptosis. Nature (Lond.). 343:170173.

50. Savill, J., N. Hogg, Y. Ren, and C. Haslett. 1992. Thrombospondin cooperates with CD36 and the vitronectin receptor in macrophage recognition of neutrophils undergoing apoptosis. J. Clin. Invest. 90:1513-1522.

51. Ortiz, A., S. L. Karp, T. M. Danoff, and E. G. Neilson. 1993. Expression of survival promoting Bcl-2 oncogene by renal cells and whole kidney. J. Am. Soc. Nephrol. 4:742a. (Abstr.)

52. Oritz, A., and E. G. Neilson. 1993. Apoptosis-related Fas RNA is expressed by renal cells and increased in renal damage. J. Am. Soc. Nephrol. 4:496a. (Abstr.)

53. Schumer, M., I. S. Sawczuk, M. C. Colombel, G. Gobé, J. Connor, K. M. O'Toole, C. A. Olsson, G. J. Wise, and R. Buttyan. 1992. Morphologic, biochemical and molecular evidence of apoptosis during the reperfusion phase after brief periods of renal ischemia. Am. J. Pathol. 140:831-838. 